\title{
Value Added Tax on Cross-Border Digital Supplies: The Kenyan Approach under the Finance Act 2019
}

\author{
Abdullahi Ali *
}

\begin{abstract}
Advancements in the global digital economy have resulted in high levels of profitability for enterprises operating within it. The digital economy is particularly challenging for tax authorities the world over, as it is characterised by an unparalleled reliance on intangible assets and a difficulty in determining the jurisdiction in which value creation occurs. It is against this backdrop that Kenya enacted the Finance Act 2019, that had amongst its objectives, the effective taxation on the consumption of cross-border digital supplies. The amendments are largely targeted at the taxation of imported digital supplies from foreign jurisdictions to final consumers in Kenya. They place the responsibility of tax assessment and remittance to the consumer of the service. This move presents a critical departure from the previous regime where the responsibility of Value Added Tax (VAT) assessment and remittance fell on the firms supplying the service squarely. This paper critically assesses the practical efficacy and inherent weaknesses arising from the potential implementation of the proposed amendments under the VAT Act and provides recommendations on the way forward.
\end{abstract}

The author is a candidate at the Kenya School of Law (Nairobi, Kenya) and holds an LLB from Strathmore Law School (Nairobi, Kenya). He would like to thank Abdulmalik Sugow and Jentrix Wanyama for their invaluable support. 
Keywords: Digital Economy, Digital Taxation, Assessment, Finance Act, Global Digital Economy, VAT

\section{TABLE OF Contents}

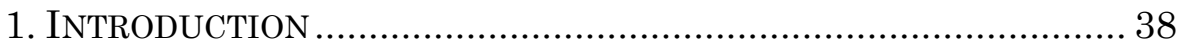

2. DigiTAL ECONOMY: AN OUTLOOK............................................... 42

2.1. Nature of the Digital Economy .......................................... 42

2.2. Digitisation and Economic Growth ................................. 43

2.3. Inherent Tax Collection Challenges ................................. 45

2.3.1. Mobility of Intangibles ............................................... 46

2.3.2. Mobility of Users and Customers............................... 46

2.3.3. Mobility of Business Functions ................................ 47

3. VALUE ADDED TAX: AN OVERVIEW …...................................... 47

3.1. Brief Overview .................................................................. 47

3.2. Value Added Tax and International Trade....................... 49

3.2.1. International Trade in Goods .................................... 49

3.2.2. International Trade in Services ................................ 49

4. VAT AND CROSS-BORDER DIGITAL SUPPLIES:

THE KENYAN APPROACH ......................................................... 52

4.1. Amendment to Interpretation Section of the

VAT Act on the Supply of Imported Services ..................... 53

4.2. Amendment to the Charging Section of the VAT Act ......... 54

4.3. Amendment to the Treatment of Imported Services ........... 55

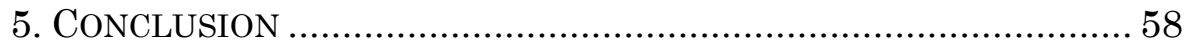

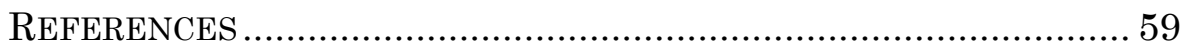

\section{INTRODUCTION}

The technological revolution that has characterised human life over the last two centuries has led to immense changes in all fields of knowledge. The rapid pace at which innovation is, and has been moving at, has proven to be a challenge for regulators as they play catch up. One manifestation of the said revolution has been the ability of commerce to go beyond the brick and mortar world, and into the ethereal cyber-space, characterised by its virtual and intangible nature. Furthermore, technological innovation has propelled the inter-connectedness and inter-dependence of the 
Journal of Intellectual Property and Information Technology Law (JIPIT) global economy linking up capital, labour, finance, and trade inextricably. ${ }^{1}$

Considerable public angst has been witnessed the world over, owing to aggressive tax planning strategies by multinational enterprises. Creative accountants and lawyers have exploited the existing panacea amongst the taxation laws of different jurisdictions to reduce their taxable base artificially by shifting their profits from high tax to low-tax jurisdictions (OECD, BEPS, 2019). It is the norm that little to no substantial economic value is created within the low-tax jurisdictions. Moreover, owing to economic downturns that have resulted in recessions, the high-tax jurisdictions have been forced to tighten their fiscal belts through austerity cuts on social spending (Curwen, 2016). This has fuelled the heightened awareness and increasing sense of indignation as to whether multinationals are paying their 'fair share' of taxation owed to the countries where much economic benefit is created (Corwin, 2014). Following the 2008 global financial crisis, investigative reporting has unearthed leaks such as the Panama and Paradise papers that have further fuelled public anger over the extent to which the mega-rich avoid taxation in the economies in which they generate huge sums of profits (Hoppkins \& Bengtsson, 2017; Polychroniu, 2016).

Kenya particularly finds itself in a precarious economic situation as the Kenya Revenue Authority (KRA) has failed to achieve its yearly revenue targets (Obiero, 2018). Moreover, public debt has increased threefold in the space of six years; from Kenya Shillings (KES) 1.8 trillion to KES 6 trillion (Central Bank of Kenya, 2020; Ndii, 2019). Concerns relating to the sustainability of Kenya's public debt and unmet revenue collection targets by the International Monetary Fund have led to increased taxation such as the highly controversial Value Added Tax (VAT) on fuel (Otieno, 2018). Moreover, Kenya is estimated to have lost up to KES 144 billion-approximately $10 \%$ of annual revenue-in the financial

1 See the global impact of the 2008 US financial crisis that had negative impacts on countries geographically distant from the United States, such as Singapore and Southeast Asian states. Thangavelu, 2008. 
Abdullahi Ali

year 2018/19 through tax avoidance, which was made possible by aggressive tax planning strategies (Wasuna, 2019).

One key avenue through which aggressive tax planning strategies draw their success is the digital economy. Players operating within the digital economy often derive huge profits without appropriate and adequate taxation (Estevão, 2019). The digital economy for taxation purposes, is characterised by its heavy reliance on intangible assets, and a difficulty in determining the jurisdiction in which value creation occurs (OECD Base Erosion and Profit Shifting Project, 2015). Certainly, a variety of taxes are applicable to various transactions and business outcomes in the digital economy. However, this paper focuses on the challenges the digital economy poses to the VAT regime. VAT is an indirect tax that is levied on the consumption of goods or services (Ebrill, Keen, Bodin \& Summers, 2001).

Effective tax collection on the consumption of digital services has proved to be an arduous endeavour for tax authorities as the very nature of the digital economy does not conform to the traditional rules that underpin the VAT regime. ${ }^{2}$ At its core, VAT is assessed and remitted by the firms involved in the value addition chain of any product/service and is charged on the final consumer (Carlson, 1980). Firms incur VAT when they purchase raw materials but since they are not taxable persons under the VAT regime, they are entitled to a refund of the VAT they have incurred when they sell the processed products/services. This method of placing the responsibility of assessing and remitting VAT to the firms involved in the value addition chain is advantageous for the tax authority on two fronts. On the one hand, firms are incentivised to recover the VAT incurred on their purchases of supplies, and remit the VAT paid by the consumer to the tax authority thereby reducing the administration and collection costs by the tax authority. On the other hand, consumers, who would have otherwise been disincentivised to comply through self-assessment, do not incur compliance costs as VAT is already included in the cost of the product/service at the point of sale (Ebrill et al., 2001).

2 See Part III for an exposition on the basic rules that underpin the VAT regime. 
VAT's overarching principle of taxing final consumption has cemented the destination principle as the theoretical justification for allocating the taxing right over cross-border supply of services to the jurisdiction of final consumption (Ebrill et al., 2001). Take the case of Showmax, which is an online movie streaming site with no physical presence in Kenya (Showmax, About us). A consumer in Mandera, Kenya, with access to the Internet, can pay for a Showmax subscription and stream movies online. However, this subscription payment is not VAT inclusive as monitoring of crossborder flows of digital services is an almost impossible task. More importantly, owing to their intangible nature, they cannot be subject to the same border controls as physical goods being imported through the country's points of entry. To compound this, the proliferation of Internet access has enabled consumers to access cross-border services without the need for the supplier to establish physical presence in the jurisdiction of consumption (OECD Base Erosion and Profit Shifting Project, 2015). Kenya's tax policymakers, just like many tax policymakers across the world, are dissatisfied with their inability to collect revenue from commercial activities within the digital economy (Ilako, 2019). With a view to expanding the tax bracket to incorporate the players operating in the digital economy, Parliament enacted the Finance Act 2019, which proposed amendments to the VAT Act touching on the supply of imported digital services (Finance Act 2019, 2021).

The amendments are largely targeted at the taxation of imported digital supplies from foreign jurisdictions to final consumers in Kenya. They place the responsibility of tax assessment and remittance to the consumer of the service. This move presents a critical departure from the previous regime where the responsibility of VAT assessment and remittance fell squarely on the firms supplying the service. This paper seeks to critique the practical efficacy of the implementation of the proposed amendments and provides recommendations for the way forward.

Part one of this paper is this introduction. Owing to the importance of the digital economy to a state's economic growth, part two assesses the nature of the digital economy, the policies various states have undertaken to spur its growth, and the 
Abdullahi Ali

resulting inherent tax collection challenges that have arisen. With a focus on the imposition of VAT on the digital economy, part three proceeds to provide an overview of VAT as well as its application with respect to international trade in goods and services. It highlights the accepted standards on taxation of cross-border supplies in goods and services while addressing the challenges the digital economy poses for VAT collection and administration. Part four critically assesses the practical efficacy and inherent weaknesses arising from the potential implementation of the proposed amendments under Kenya's Finance Act 2019. Part five concludes the study and makes certain recommendations.

\section{Digital ECONOMY: AN OUTLOOK}

The world today is characterised by people's sustained use of digital technologies. From mobile phones, to computers, technology has made the execution of tasks, and the creation of new knowledge expedient and easier (UNCTAD, 2019). With previously unconnected people becoming connected to the digital world increasingly, and more value chains being connected digitally, its importance is likely to grow further. This part provides an exposition of the nature of the digital economy, establishing its importance to the overall economic growth of countries. It is against this backdrop that the paper analyses Kenya's agenda for spurring the growth of the digital economy to reap the resulting commercial benefits. Given the resulting increase in profitability of enterprises operating within the digital economy, this part concludes by assessing the inherent tax collection challenges of commercial activities within the digital economy.

\subsection{Nature of the Digital Economy}

The adoption of a precise and universal definition of the digital economy has been a fundamental challenge. This has been occasioned by the rapid rate at which technology is advancing thereby rendering that which would be considered revolutionary one day, obsolete the next (Barefoot, Curtis, Jolliff, Nicholson, \& Omohundro, 2018). Recent attempts have focused on the 
Journal of Intellectual Property and Information Technology Law (JIPIT) distinction between digitisation and digitalisation as the twin pillars underpinning any holistic understanding of the digital economy (Brennen \& Kreiss 2014; UNCTAD Digital Economy Report, 2019; Kenya Digital Economy Blueprint, 2019 \& Accenture Strategy, 2016)). Brennen \& Kreiss (2014) define digitisation as the material process of converting individual analogue streams of information into digital bits, and digitalisation as the way many domains of social life are restructured around digital communication and media infrastructures (Brennen \& Kreiss 2014).

The digital economy founded on the aforementioned twin pillars therefore exhibits a broad application and is aptly summated in the definition by (Bukht and Heek, 2017), "the digital economy is that part of economic output derived solely or primarily from digital technologies with a business model based on digital goods". This broader appreciation is also shared by Knickrehm, Berthon and Daugherty who provide that the digital economy is "the share of the total economic output derived from a number of broad digital inputs which include digital skills, digital equipment and the intermediate digital goods and services used in production" (Accenture Strategy, 2016). However, the Organisation for Economic Cooperation and Development (OECD), in its report targeted at addressing the prevailing difficulties facing tax authorities in collecting revenues from the digital economy, provided that the digital economy "is characterised by unparalleled reliance on intangible assets, massive use of data (notably personal data)... and the difficulty in determining the jurisdiction in which value creation occurs (emphasis added)" (OECD Base Erosion and Profit Shifting Project, 2015). The virtual nature of the digital economy is key to understanding the challenges faced by tax authorities in tapping into revenues generated from commercial ventures within it.

\subsection{Digitisation and Economic Growth}

The contribution of digitalisation to the revolutionisation of business processes, enhancing productivity and overall economic development has led to a recognition by states on the need to enact 
Abdullahi Ali

policies and promote incentives that ensure sustained innovation and continued value generation from the digital economy. States that have developed an environment that fosters technological development and continued growth in their digital economies continue to reap huge benefits. Arguably, the United States of America (USA) is leading the way in this respect. Seven out of the ten most valuable technology companies in the world-by market capitalisation-are American companies, with two Chinese companies and one South Korean company completing the list (Parietti, 2019). Therefore, many governments, especially in the developing world, have sought to foster an environment that will sustain technological innovation and growth in the digital economy with a view to boosting their competitiveness, economic growth, and social well-being (OECD Digital Economy Outlook, 2015).

Developing economies in particular, are enjoying a higher share of Gross Domestic Product (GDP) growth owing to the development of digital technologies. Estimates point to $15-25 \%$ annual growth in their digital economies thereby disrupting economic processes, systems and sectors, reshaping existing consumer behaviour, business interactions, and business models (World Economic Forum, 2020; Bukht and Heek, 2017). Kenya is not left out of this trend; the value of the digital economy grew by 12.9\% in 2019 (Kenya Digital Economy Blueprint, 2019). Internet connectivity has expanded to the most remote parts of Kenya owing to increasing number of active mobile telephone subscriptions with $3 \mathrm{G}$ and $4 \mathrm{G}$ network connectivity, and availability of affordable smartphones with affordable data plans. The Communications Authority of Kenya, for the quarter ended September 2019, estimated that the total internet subscriptions, through data or broadband, stood at 52 million subscriptions (Communication Authority of Kenya, 2019).

Kenya, in its Digital Economy Blueprint, identifies many enablers of the digital economy that underpins its vision of developing coherent policies that will ensure its success. These include: enacting mechanisms that will reduce the regulatory and inefficient practical hurdles to doing business; ensuring the protection of consumer rights and interests online and fostering a 
Journal of Intellectual Property and Information Technology Law (JIPIT)

trustworthy online environment; establishing a clear legal and regulatory framework that ensures data protection of Internet users; and ensuring the protection and integrity of electronic and digital systems through appropriate cyber-security measures (Kenya Digital Economy Blueprint, 2019).

\subsection{Inherent Tax Collection Challenges}

The sustained growth of the digital economy has led to businesses capturing value where there was none. The wideranging impact of the digital economy is matched by its capacity to create diverse revenue models that take advantage of the aforementioned value-creation. The innovative revenue models that are within the scope of this paper include; digital content purchases or rentals for example e-books, videos, apps, games and music; subscription-based revenues, for instance, periodic payments for premium delivery, digital content such as news, music and movie streaming; and licensing content and technology granting access to software, algorithms or specialist technology systems (OECD Base Erosion and Profit Shifting Project, 2015).

This value-creation and revenue-generation is of paramount interest to tax authorities that seek to ensure the appropriate collection of tax from revenues accruing to this economy. However, the nature of the digital economy poses an enormous task to the tax authorities as the traditional rules are largely considered incapable of confronting the prevailing challenges posed by the rapid growth of the digital economy (Cockfield, 2014).

The threat posed to the collection of VAT on the consumption of services through digital mediums is as a result of the digital economy's largely mobile nature. The OECD addresses the mobility dilemma along three disparate fronts; mobility with respect to the intangibles upon which the digital economy relies; mobility with respect to users and customers; and mobility with respect to business functions (OECD Base Erosion and Profit Shifting Project, 2015). 
Abdullahi Ali

\subsubsection{Mobility of Intangibles}

There is no universal definition of what constitutes an intangible asset thereby inflaming disputes between taxpayers and tax administrations (Gatuyu, 2019). According to the International Accounting Standards Board, intangible assets are "non-monetary assets which are without physical substance and identifiable either separable or arising from contractual or other legal rights" (International Accounting Standard, 2016). Investment in, and the development of, intangibles is essential to continued value creation and growth for entities operating within the digital economy. For example, an over-reliance on software means companies will expend substantial resources on research and development to upgrade existing software or develop new software with the objective of remaining competitive and improving user experience (OECD Base Erosion and Profit Shifting Project, 2015).

The digital evolution of the film industry from the purchasing of hardcopy DVD's in brick and mortar stores to one of purchasing periodic subscription plans that permit unlimited viewing online is one key characteristic of the widespread adoption of intangibles in the digital economy. Under existing tax rules, online movie streaming sites such as Netflix can easily assign or transfer the rights to their intangibles among associated enterprises located in different jurisdictions almost at a click of a button, resulting in the legal ownership of the assets being separated from the activities that developed those intangibles (OECD Base Erosion and Profit Shifting Project, 2015).

\subsubsection{Mobility of Users and Customers}

As previously established, expanded connectivity and Internet penetration means that users can carry on commercial activities remotely while travelling across borders. An individual can reside in one country, purchase an application while staying in a second country and use the application while in third country. According to the OECD, this challenge is exacerbated by the development of virtual private network technology (VPNs) that may, whether intentionally or unintentionally, disguise the identity of the user or 
Journal of Intellectual Property and Information Technology Law (JIPIT)

the location at which a commercial activity actually took place (OECD Base Erosion and Profit Shifting Project, 2015). Moreover, search engines that are heavily encrypted such as TOR make it virtually impossible to identify the user or the location in which the user is accessing the Internet (Dredge, 2013).

\subsubsection{Mobility of Business Functions}

Advancements in the digital economy have led to a dramatic reduction in the costs of organising and coordinating complex activities over long distances. Therefore, businesses are able to manage their global operations from a central location that may be removed geographically from the location in which their suppliers or customers may be located (OECD Base Erosion and Profit Shifting Project, 2015). This has resulted in the ability of a consumer to access a service in the digital marketplace without having to leave the comforts of their premises.

\section{VALUe AdDED TAX: AN Overview}

Moving on from an understanding of the digital economy and the inherent tax collection challenges, this part begins by providing a brief overview of the nature of VAT and the computation of VAT in a taxable transaction. It then assesses the applicability of VAT in cross-border supplies of goods and services. Significant challenges arise with respect to charging VAT on the cross-border supply of services. The paper then assesses the prevailing challenges and solutions proposed by commentators.

\subsection{Brief Overview}

A typical firm involved in the production of a good or a service would ordinarily seek raw materials, utilise its labour and capital equipment in processing the raw materials into finished goods or services, and proceed to sell the finished product. That difference between the cost at which the firm acquired the raw materials and the price at which the firm charges at point of sale is considered the value that the firm has added (Shoup, 1955). Therefore, VAT is 
Abdullahi Ali

essentially a tax charged on the consumption of goods or services. The process through which VAT is assessed and collected is referred to as a staged collection process and is depicted below (OECD, International VAT/GST, 2014).

Take the example (ACCA, 2018), of a forester who sells wood to a furniture maker for KES 5,000 plus VAT. ${ }^{3}$ The furniture maker uses this wood to make a dining table and sells the table to the furniture shop for KES 10,000 plus VAT. The furniture shop then sells the dining table to the final consumer for KES 20,000 plus VAT. The following illustration depicts the staged collection process that forms the basis that the KRA would collect VAT.

Table $n^{\circ} 1$

\begin{tabular}{lrrrrr}
\hline & $\begin{array}{rrrr}\text { Cost } \\
\text { KES }\end{array}$ & $\begin{array}{r}\text { Input } \\
\text { Tax 16\% } \\
\text { KES }\end{array}$ & $\begin{array}{r}\text { Net Sale } \\
\text { Price } \\
\text { KES }\end{array}$ & $\begin{array}{r}\text { Output } \\
\text { Tax 16\% } \\
\text { KES }\end{array}$ & $\begin{array}{r}\text { Payable } \\
\text { to KRA } \\
\text { KES }\end{array}$ \\
\hline Forester & 0 & 0 & 5,000 & 800 & 800 \\
Furniture maker & 5,000 & 800 & 10,000 & 1,600 & 800 \\
Furniture Shop & 10,000 & 1,600 & 20,000 & 3,200 & 1,600 \\
\hline & & & & & $\mathbf{3 , 2 0 0}$
\end{tabular}

A VAT of $16 \%$ is chargeable on any good/service that is consumed by any party at the conclusion of each stage (Value Added Tax Act 2013, 2021). Despite the fact that VAT is charged on the purchases that firms make, they are allowed to recover any input VAT paid on the purchase of supplies. In this case, the furniture maker paid KES 800 input VAT and charged the furniture shop KES 1600 output VAT. The furniture maker is allowed to recover the KES 800 input VAT it paid to the forester and remit the balance of KES 800 to KRA. This process has the effect of extending the total VAT amount charged on a product throughout its value-addition journey, to the end consumer.

3 Plus VAT is used to refer to the cost of the product without the addition of VAT. 
Journal of Intellectual Property and Information Technology Law (JIPIT)

\subsection{Value Added Tax and International Trade}

The fundamental dilemma arising with respect to VAT and international trade is the jurisdiction that has the right to charge VAT on the consumption of a good/service. Should it be the jurisdiction from which the good/service originates or the jurisdiction in which the good/service is destined for consumption? International consensus points to the adoption of the destination principle owing to VAT's overarching principle that it ought to be borne by the final consumer (Agreement on Subsidies and Countervailing Measures, 2020). Therefore, firms that export goods or services do not include VAT in the price they charge at the point of sale. They are therefore entitled to a refund from the tax authority of their jurisdiction on any input taxes they incurred in the entire value addition chain (a process referred to as 'zerorating'). The importing jurisdiction then charges VAT at its own rate at point of entry on the good/service destined for consumption.

\subsubsection{International Trade in Goods}

The charging of VAT by the importing jurisdiction with respect to goods is relatively straightforward as it is charged at the jurisdiction's point of entry. Take the example of a car being imported through the port of Mombasa, the VAT will be charged alongside all the other prevailing taxes chargeable at the point of entry.

\subsubsection{International Trade in Services}

Owing to the intangible nature of services, developing a pragmatic and effective method of collecting VAT is not as easy as it is in the case of goods. Take an instance where a Rwandan-based consultancy firm provides a service that is used by a firm in Kenya. Is the service supplied in Rwanda or in Kenya? It is noteworthy to point out that the service can either be consumed by a business customer, thereby constituting a business to business supply (B2B) or a final consumer constituting a business to customer supply (B2C). Ebrill et al. (2001). provide two main approaches to dealing with such a conundrum. In the first approach, one would deem the 
jurisdiction in which the customer is resident, Kenya, as the jurisdiction of supply. Therefore, the supply is zero-rated in the jurisdiction of the supplier (Rwanda), and the service is subject to VAT at the Kenyan rate. This approach would require the Rwandan supplier to register in Kenya and remit the VAT to KRA. Business customers would be able to offset the input tax they paid on the consultancy service against the sales they would subsequently make to their final consumer. However, the final consumer would pay the tax on the service received without being able to recover it. In the second approach, one would deem the jurisdiction in which the supplier is resident, Rwanda, the jurisdiction of supply. Therefore, the supplier would be liable to remit VAT to the Rwandan tax authority for the service supplied abroad. In such a case, the Kenyan business customer would be able to apply to the Rwandan tax authority to recover the input tax paid on purchases whereas the final consumer of the service would pay VAT in Rwanda despite the service being consumed in Kenya.

The first approach is the traditionally applicable approach as suppliers would be expected to register and remit the VAT due in whichever jurisdiction their supplies are consumed in accordance with that jurisdiction's VAT regime (OECD, International VAT/GST, 2014). This is largely due to its satisfaction of the destination principle and the resulting reduction in the practical challenges and administrative costs that would arise from crossborder VAT refunds as regards B2B transactions. Moreover, the UN's Manual on Statistics of International Trade in Services provides that most services would traditionally be 'nontransportable' and their international supplies would occur through the physical geographical movement of one or the corresponding party to the transaction; the customer or supplier (United Nations, 2009). This would therefore make it simpler to charge VAT as the service is supplied in the jurisdiction of consumption. However, the growth of the global economy, and the emergence of digital supplies has led to greater scrutiny with regard to the application of these rules on cross-border supplies of services (Lamensch, 2012). 
Journal of Intellectual Property and Information Technology Law (JIPIT)

As earlier explained, a supplier of a service to a foreign jurisdiction would be required to register in that jurisdiction of consumption, collect and remit the VAT to the relevant tax authority -in line with Brill's first approach. This approach raised the compliance burden of international suppliers and therefore legislators developed the reverse-charge mechanism so as to ease this compliance burden. The reverse-charge mechanism, which would only apply to B2B transactions, is essentially a shift in the tax assessment and collection obligations from the supplier to the business consumer (OECD Base Erosion and Profit Shifting Project, 2015). Practically, therefore, the supplies would be zerorated at the jurisdiction of origin and business consumers in the jurisdiction of consumption would be liable to assess and remit the tax due through the legally provided tax period (Value Added Tax Act 2013, 2021). The mechanism is convenient as business customers who are already registered for tax purposes in their own jurisdiction would comply with their tax obligations with the incentive of offsetting their input taxes against output taxes. Moreover, it reduces administrative costs for the tax authorities as they do not have to handle a large number of registrations for a limited number of taxable supplies within their territory (Lamensch, 2012).

However, implementing the destination principle for $\mathrm{B} 2 \mathrm{C}$ cross-border digital supplies would be quite challenging on two fronts. First, relying on voluntary registration of suppliers in the jurisdiction of consumption so as to remit VAT has no apparent enforcement mechanism. Secondly, zero-rating cross-border supplies from the supplier's jurisdiction and relying on the customer to self-assess VAT would lead to widespread non-taxation in practice (OECD Base Erosion and Profit Shifting Project, 2015). The complexity and inordinately high compliance costs that would arise owing to legal demand for tax residents to keep record of all their consumption in any tax year with the objective of ensuring compliance with VAT laws ought to discredit such an approach.

This apparent impasse has been the subject of debate, most recently in the OECD's report on addressing the tax challenges of the digital economy (OECD Base Erosion and Profit Shifting 
Abdullahi Ali

Project, 2015). At the time of writing this paper, there still is no international consensus on how to effectively ensure VAT on final consumption of cross-border supplied services is appropriately charged in the jurisdiction of consumption. Any possible consensus must result in a system that ensures the supplier collects and remits the VAT due on the consumption of their service at the rate prescribed by the jurisdiction of consumption.

\section{VAT AND CROSS-BORDER DIGITAL SUPPLIES: THE KENYAN APPROACH}

Given the prevailing impasse at the international level with respect to adequate taxation of VAT on cross-border supplies of digital services, Kenya sought to address this issue unilaterally. This part assesses the practical efficacy of the approach Kenya has taken under the Finance Act, 2019, to ensure appropriate charging of VAT on consumption of cross-border supplies of digital services.

Corwin in her David Tillinghast lecture on international taxation addressed the general populace's growing discontent with the manner in which multi-national enterprises would avoid taxation through complex structures of subsidiaries and affiliates (Corwin, 2015). This discontent came at a time when austerity measures had led to cuts in government spending and drastic increases in taxation of the average citizen. The key theme underpinning her lecture was the exploration of the relative merits of making consequential policy decisions based on passion versus logic and common sense (Corwin, 2015). In her view, a key distinction ought to be made between mainstreaming of the tax morality question, viz, whether multi-national enterprises are paying their fair share on the one hand, and legitimate policy considerations that require sensible thinking on the other. This distinction in effective tax policy considerations is what this paper refers to as the 'Corwinian test'.

Kenya's public outcry over tax avoidance did crescendo during the Senate hearings targeted at developing a tax regime that can include operators in the digital economy in the tax bracket. The 
Journal of Intellectual Property and Information Technology Law (JIPIT)

Senator of Nairobi County, perplexed at taxi-hailing apps that operated in the country, was quoted saying:

According to testimonies-and I have had meetings with these drivers of hailing cabs, UBER, Taxify and Little Cab-the drivers have to work extremely long hours just to make a basic living, with some taking home less than the average minimum wage after paying their running costs. The fares being charged by these hailing cab companies are extremely low and below the minimum rates prescribed by the Automobile Association and the Government, and the commissions taken are too high! As soon as a customer pays for an UBER ride, $25 \%$ immediately goes to the company in Netherlands and nothing comes to our country! (Sunday, 2015).

Kenya's Legislature soon thereafter enacted the (Finance Act 2019, 2021), which had amongst its essential objectives, the taxing of the digital economy. This paper assesses the amendments to the VAT Act in accordance with the Corwinian test. ${ }^{4}$ Do the amendments to the VAT Act reflect and address the longstanding international policy debates targeted at the challenges arising out of taxation of the digital economy or are they a result of passion, emotion and highly charged rhetoric that could in the long run not advance the real underlying policy concerns? (Corwin, 2015).

The Finance Act made three main amendments to the VAT Act. Each of these amendments, their implications, and potential for practical efficacy are addressed below.

\subsection{Amendment to Interpretation Section of the VAT Act on the Supply of Imported Services}

The VAT Act provides:

Supply of imported services means a supply that satisfies the following conditions,

a) The supply is made by a person who is not a registered person to any person;

4 Certainly, the Finance Act addresses other taxes and the digital economy and how the Kenyan legislature plans on drawing them into the tax base, however, this study will only focus on those amendments touching on the VAT Act. 
b) The supply would have been a taxable supply if it had been made in Kenya; and

c) The person would not have been entitled to a credit for the full amount of input tax payable if the services had been acquired by the person in a taxable supply (Finance Act 2019, 2021).

The first amendment replaces the previous phrase, "supply made ... to a registered person..." thereby introducing the consumer (be it a business consumer or the final consumer) as a directly responsible party in the VAT collection process. This is an important departure from the previous regime as VAT is generally designed as an indirect tax meaning that, in as much as the tax is borne by the final consumer of the service, it is collected from the supplier of the service.

\subsection{Amendment to the Charging Section of the VAT Act}

The VAT Act provides for the following amendments to Section 5's respective subsections:

1) A tax, to be known as value added tax, shall be charged in accordance with the provisions of this Act on,

(a) a taxable supply made by a registered person in Kenya;

(b) the importation of taxable goods; and

(c) a supply of imported taxable services.

6) Tax on the supply of imported taxable services shall be a liability of any person receiving the supply and, subject to the provisions of this Act relating to accounting and payment, shall become due at the time of the supply.

(7) The provisions of subsection (1) shall be applicable to supplies made through a digital marketplace.

(8) The Cabinet Secretary shall make regulations to provide the mechanisms for implementing the provisions of subsection (7).

(9) For the purpose of this section, "digital marketplace" means a platform that enables the direct interaction between buyers and sellers of goods and services through electronic means. (Finance Act 2019, 2021).

The second amendment, under section 5(6), establishes the consumer of the imported service as directly responsible for assessing and remitting the VAT at the time of supply. The particular imported services targeted, are those made through the 
Journal of Intellectual Property and Information Technology Law (JIPIT)

digital marketplace. The administration of this position will require new regulations. Section 5(7) also provides that the Cabinet Secretary of the Treasury will develop regulations to provide the mechanisms for implementing the taxation of imported digital services. At time of writing this paper, the regulations had not been enacted. However, the Cabinet Secretary had developed draft regulations that have circulated for public participation and invitation of comments (Draft Value Added Tax (Digital Marketplace Supply) Regulations, 2020). The draft regulations are silent on the exact mechanism through which consumers would be expected to assess and remit VAT on their consumption. However, the draft regulations do provide for a simplified VAT registration framework through which foreign suppliers of digital supplies in Kenya can register and remit the VAT incurred on digital supplies. The regulations therefore fail to address the key requirement made by the Finance Act in ensuring the consumer in a B2C supply incur the tax liability and the exact mechanism through which this requirement ought to be effected.

\subsection{Amendment to the Treatment of Imported Services}

The VAT Act provides for the following amendments to Section 10's respective subsections:

1) If a supply of imported taxable services is made to any person, the person shall be deemed to have made a taxable supply to himself.

3) The output tax in respect of a deemed taxable supply under subsection (1) shall be payable by any person at the time of the supply (Finance Act 2019, 2021).

Summarily, the amendments to the VAT Act require the final consumer of the cross-border digital service to self-assess all consumption of an imported digital service and assess the relevant tax due and remit it to KRA. Essentially, the amendments extend the application of the reverse-charge mechanism for VAT collection that previously only applied to business consumers, to final consumers as well. 
However, the application of the reverse-charge mechanism to cross-border B2C supplies raises significant questions as to its implementation. It is an accepted international norm that the reverse-charge mechanism is not fit for $\mathrm{B} 2 \mathrm{C}$ cross-border supplies for various reasons. For instance, consumers are not registered persons, do not have the skills to voluntarily proceed with the remittance of VAT, and do not have the incentive-unlike businesses - to recover any of the input tax they would pay for their supplies (Lamensch, 2012). Therefore, the level of compliance is likely to be low and the enforcement of the collection of small amounts of VAT from large numbers of private consumers is likely to involve inordinately high administrative and compliance costs to the revenue authority that would outweigh the revenue that would be collected (OECD, International VAT/GST, 2014).

For instance, prevailing data points to the fact that Kenya has failed to ensure its taxpayers self-assess appropriately and remit the tax due for the annual income tax. The total number of registered taxpayers in Kenya who filed their income tax returns for the financial year 2018/19 were slightly over 3.8 million (Kenya Revenue Authority, 2019), whereas the country has a little over 19.6 million registered voters (Independent Electoral \& Boundaries Commission), with an overall population of 47.5 million people (Kenya Population and Housing Census Results, 2019.) Therefore, the entirety of Kenyan taxpayers who filed their returns account for just $19 \%$ of those who are over 18 years of age and $8 \%$ of the entire population. The data on filing of income tax returns is key to the analysis in this paper as the application of the reverse-charge mechanism to the final consumer relies heavily on self-assessment on the part of the consumer. The low compliance rate in the selfassessment for those over 18 years of age for income tax does not bode well for the Legislature's intention to rely on self-assessment of final consumers in the collection of VAT on the consumption of digital supplies. Moreover, a key principle of revenue collection is efficiency, which mandates the compliance costs for consumers, and administration costs for revenue authorities, should be minimised as much as possible (Mankiw, Yagan, \& Weinzierl, 2009). The application of the reverse-charge mechanism to final 
Journal of Intellectual Property and Information Technology Law (JIPIT)

consumers is likely to result in a disproportionate level of administration costs to the potential revenue collected. Furthermore, the characteristics of the digital space provided previously, highlight the increasing mobility of the consumer as a key challenge to the effective taxation of digital supplies. A Kenyan consumer savvy with the use of a VPN is capable of hiding one's online identity thereby circumventing any probability of tax liability enforcement.

The OECD in its VAT guidelines provides that the most effective and efficient approach to the appropriate collection of VAT on cross-border B2C supplies is to require the non-resident supplier to register and account for the VAT in the jurisdiction of the consumer thereby enforcing the destination Draft Value Added Tax (Digital Marketplace Supply, Regulations, 2020) principle (OECD, International VAT/GST, 2014). However, this approach largely relies on the voluntary registration of the non-resident supplier in the jurisdiction of the consumer. The VAT guidelines recommend two major anchor points to promote voluntary registration. First, when implementing a registration-based collection mechanism, tax authorities should establish a simplified registration and compliance regime that is limited to what is strictly necessary for the effective collection of the VAT (OECD, International VAT/GST, 2014). This would be essential for non-resident suppliers that supply digital services to multiple jurisdictions. Secondly, it is necessary to enhance taxing authorities' enforcement capacities through international cooperation focused on the exchange of information, and on assistance in recovery of due taxes (OECD, International VAT/GST, 2014). The guidelines further provide that mutual administrative assistance is a key means to achieving the proper collection and remittance of the tax on cross-border supplies of services and intangibles by non-resident suppliers. It will also be helpful in identifying suppliers, verifying the status of customers, monitoring the volume of supplies, and ensuring that the proper amount of tax is charged (OECD, International VAT/GST, 2014).

It is important to note that the aforementioned approach is the same the draft regulations attempt to take (Draft Value Added Tax (Digital Marketplace Supply) Regulations, 2020). Despite 
Abdullahi Ali

providing for a simplified registration framework, they still fail to address a key requirement that the Finance Act places upon them, which is to provide for a mechanism of ensuring that consumers assess and remit their VAT obligations. Therefore, this paper contends that the Finance Act has proposed an impossible responsibility upon the Cabinet Secretary in extending the reversecharge mechanism to $\mathrm{B} 2 \mathrm{C}$ transactions. This is evident in the manner in which the draft regulations fail to provide an enabling regulatory mechanism.

The arising complexity in identifying an effective answer to the taxation of cross-border supplies of digital services can easily be discerned from the foregoing analysis. Therefore, one cannot help but wonder whether the discussion drafts and panels of the Legislature duly reflected on the inherent weakness that would lead to a costly and ineffective implementation of the provisions.

\section{CONCLUSION}

The digital economy certainly poses fundamental threats to the possible collection of tax from its economic activities. However, long-standing debates at international fora such as the OECD and the UN Tax Committee provide an insight into the intricacies of the prevailing challenges in the taxation of economic activities within the digital economy. Undoubtedly, sovereign states have a right to tax economic activities occurring within their jurisdiction, but the nature of the digital economy has disrupted traditional rules of taxation in an unprecedented manner.

The Kenyan approach of taxing the consumption of digital supplies into Kenya from a foreign jurisdiction, by extending the application of the reverse-charge mechanism to consumers in a B2C digital supply, fails the Corwinian test. It is a legal position that is fraught with inherent weaknesses in its enforcement and will result in inordinately high compliance and administration costs. Certainly, it is a legislative approach which does not advance the real and legitimate underlying policy concerns and an observer is right to see it as a product of passion and highly charged rhetoric. The ability of multi-national enterprises operating in the digital 
economy to avoid VAT offers them a competitive advantage over domestic suppliers who have to comply with VAT legislation. It is not a fair competitive edge either, as domestic suppliers risk going out of business thereby affecting the domestic economy adversely. Definitely, there is an urgent need to ensure that operators in the digital space contribute their fair share of taxation. However, without careful thought as to the effective manner in which the tax policy-makers can deal with the enigma that is the digital economy, all efforts might not only bear no fruits, but may result in greater harm. Moreover, with an increasingly globalised world, tax policy can no longer be within the purview of individual states exclusively as abrupt legislative changes could disrupt international trade. The enormous challenges that the digital economy has had on territorial taxation in an intricately connected world will require international cooperation in advancing common solutions.

\section{REFERENCES}

ACCA. (2018). Taxation-UK Study Text. London: BPP Learning Media. Accenture Strategy. (2016). Digital Disruption: The Growth Multiplier, Optimising digital investments to realise higher productivity and growth. https://www.accenture.com/_acnmedia/pdf14/accenture-strategy-digital-disruption growth-multiplierbrazil.pdf.

Agreement on Subsidies and Countervailing Measures. (2020, February). https://www.wto.org/english/docs_e/legal_e/24-scm.pdf.

Barefoot, K., Curtis, D., Jolliff, W., Nicholson, JR. \& Omohundro, R. (2018). Defining and measuring the digital economy. Working paper 1 of the Bureau of Economic Analysis.

https://www.bea.gov/system/files/papers/WP2018-4.pdf.

Brennen, S. \& Kreiss, D. (2014, September 8). Digitalization and digitization. Culture Digitally.

Bukht, R. \& Heeks. R. (2017). Defining, Conceptualising and Measuring the Digital Economy. Working paper 68 of the Economic and Social Research Council, Development. https://diodeweb.files.wordpress.com/2017/08/diwkppr68diode.pdf.

Carlson, G. (1980). Value Added Tax: Appraisal and Outlook. Journal of Corporation Law 6(7). 
Abdullahi Ali

Central Bank of Kenya. Public Debt. https://www.centralbank.go.ke/public-debt/

Cockfield, A. (2014). BEPS and Global Digital Taxation. Tax Notes International 75(11).

Communication Authority of Kenya. (2019). First Quarter Sector Statistics Report for the Financial Year 2019/20 (JulySeptember 2019). https://ca.go.ke/wpcontent/uploads/2019/12/Sector-Statistics-Report-Q1-20192020.pdf.

Corwin, S. (2014). Sense \& Sensibility: The Policy and Politics of BEPS. Tax Notes. http://uhimik.ru/1275/1275.pdf.

Curwen, E. (2016, April 12). What is being done to tackle tax-dodging? BBC News. https://www.bbc.com/news/business-36029621.

Digital Economy Blueprint. (2019). https://www.ict.go.ke/wpcontent/uploads/2019/05/Kenya-Digital-Economy-2019.pdf.

Draft Value Added Tax (Digital Marketplace Supply) Regulations 2020, (2021, May). https://kra.go.ke/images/publications/Draft-VATDigital-Supply-Regulations-2020---29-05-2020.pdf.

Dredge, S. (2013, November 5). What is TOR? A Beginner's Guide to the Privacy Tool. The Guardian.

https://www.theguardian.com/technology/2013/nov/05/torbeginners-guide-nsa-browser.

Ebrill, L., Keen, M., Bodin, J. and Summers. V. (2001). The Modern VAT. Washington: International Monetary Fund.

Estevão, M. (2019, November 20). Pushing for tax fairness in a digital world. World Economic Forum.

https://www.weforum.org/agenda/2019/11/pushing-for-taxfairness-in-a-digital-world/.

Finance Act 2019. (2021, May). Retrieved from eKLR.

Gatuyu, J. (2019). Taxing a Digital Economy: Exploring Intangibles Assets to Broaden Revenue Base in Kenya. Strathmore Law Review 4(1).

Hoppkins, N. \& Bengtsson, H. (2017, November 5). What are the Paradise Papers and what do they tell us? The Guardian. https://www.theguardian.com/news/2017/nov/05/what-are-theparadise-papers-and-what-do-they-tell-us.

Independent Electoral \& Boundaries Commission, Statistics of voters. https://www.iebc.or.ke/registration/?stats. 
Journal of Intellectual Property and Information Technology Law (JIPIT)

Ilako, C. (2019, October 11). KRA goes after digital economy to boost collection. The Star. https://www.the-star.co.ke/business/201910-11-kra-goes-after-digital-economy-to-boost-collection/.

International Accounting Standard (2016). No. 38. https://www.icpak.com/wp-content/uploads/2016/07/IAS-38.pdf

Kenya Population and Housing Census Results. (2019). https://www.knbs.or.ke/?p=5621.

Kenya Revenue Authority. (2018/19). Annual Revenue Performance Report No. 7.

Lamensch, M. (2012). Are Reverse-Charging and the One Stop Scheme Efficient Ways to Collect VAT on Digital Supplies? World Journal of VAT/GST Law 1(1).

Mankiw, G., Yagan, D., \& Weinzierl, M. (2009). Optimal Taxation in Theory and Practice. Journal of Economic Perspectives 23(4).

Ndii, D. (2019, November 15). "I don't understand why Kenyans are broke" Mr. Kenyatta's debt distress revisited. The Elephant. https://www.theelephant.info/op-eds/2019/11/15/i-dontunderstand-why-kenyans-are-broke-mr-kenyattas-debtdistress-revisited/.

Obiero, J. (2008). Strategy Implementation and Performance of the Kenya Revenue Authority (Published MBA Thesis). Kenyatta University, Nairobi.

OECD Base Erosion and Profit Shifting Project. (2015). Addressing the Tax Challenges of the Digital Economy. Action Plan.

OECD. (2015). Digital Economy Outlook. https://read.oecdilibrary.org/science-and-technology/oecd-digital-economyoutlook-2015_9789264232440-en\#page23.

OECD, BEPS. (2019). Inclusive framework on base erosion and profit shifting. https://www.oecd.org/tax/beps/.

OECD, International VAT/GST Guidelines. (2014).

Otieno, O. (2018, September 2). IMF Fuel tax is degrading Kenya's dignity'. Daily Nation.

https://www.nation.co.ke/oped/opinion/IMF-fuel-tax-isdegrading-Kenya-s-dignity/440808-4739128-43q1ojz/index.html

Parietti, M. (2019, November 3). The Top 10 Technology Companies. Investopedia.

https://www.investopedia.com/articles/markets/030816/worldstop-10-technology-companies-aapl-googl.asp. 
Abdullahi Ali

Polychroniu, C. (2016, April). Panama Papers: Why should we care? Al Jazeera.

https://www.aljazeera.com/indepth/opinion/2016/04/panamapapers-care-160404093556156.html

Shoup, C. Theory and Background of the Value Added Tax. Proceedings of the Annual Conference on taxation under the Auspices of the National Tax Association. No. 48(7).

https://www.jstor.org/stable/pdf/23407027.pdf?refreqid=excelsio r\%3Aba5be5e3f3bd5e65a016b50d222b004a.

Showmax. About Us. https://faq.showmax.com/eng/about-us

Sunday, F. (2019, September 24). Why State faces an uphill task in taxing digital apps. Standard Digital.

https://www.standardmedia.co.ke/business/article/2001343123/ why-state-faces-an-uphill-task-in-taxing-digital-apps.

Thangavelu, S. (2008). Global Financial Crisis: Impact on Singapore and (ASEAN) Association of Southeast Asian Nations, (49(2)). Working Paper Series of the East Asian Bureau of Economic Research, EABER.

http://www.eaber.org/system/tdf/documents/WPS_2008_49.pdf?f ile $=1 \&$ type $=$ node $\&$ id $=21958 \&$ force $=$.

UNCTAD. (2019). Value Creation and Capture: Implications for Developing Countries. Digital Economy Report 3. https://unctad.org/en/PublicationsLibrary/der2019_en.pdf.

UNCTAD. (2019). Value Creation and Capture: Implications for Developing Countries. Digital Economy Report 3. https://unctad.org/en/PublicationsLibrary/der2019_en.pdf .

United Nations. (2009). Manual on Statistics of International Trade in Services.

Value Added Tax Act 2013. (2021, May). eKLR.

Wasuna, B. (2019, October 4). Inside big companies' dirty scheme of legal tax evasion. Daily Nation.

https://www.nation.co.ke/news/How-clever-traders-avoidpaying-taxes/1056-5297838-oxwqjw/index.html.

World Economic Forum. (2015). Expanding Participation and Boosting Growth: The Infrastructure Needs of a Digital Economy. http://www3.weforum.org/docs/WEFUSA_DigitalInfrastructure _Report2015.pdf. 